\title{
The Pruning Effect on the Storage Root Yield and Starch Content of Sweet Potato Clones Planted at Dry Land
}

\author{
Edyson Indawan ${ }^{1}$, Sri Umi Lestari ${ }^{1 *}$, Nurita Thiasari ${ }^{2}$ and Pramono Sasongko ${ }^{3}$ \\ ${ }^{1}$ Department of Agrotechnology, Faculty of Agriculture, Universitas Tribhuwana Tunggadewi, \\ Malang, Indonesia; ${ }^{2}$ Department of Animal Husbandry, Faculty of Agriculture, Universitas Tribhuwana \\ Tunggadewi, Malang, Indonesia; ${ }^{3}$ Department of Agricultural Industrial Technology, \\ Faculty of Agriculture, Universitas Tribhuwana Tunggadewi, Malang, Indonesia \\ ${ }^{*}$ Corresponding author: sriumi.lestari@yahoo.com
}

\begin{abstract}
Sweet potato is a dual-purpose crop, which could produce both food and feed. The vine pruning prior to storage root harvesting was intended to increase the quantity and quality of fresh forage for animal feed. This study aims to evaluate whether periodic pruning can affect the storage root yield and its starch content. This experiment employed split-plot design with two factors and three replications. The first factor as main plot was vine pruning which consisted of four distinct pruning times (four times, three times, twice and once). The second factor as sub-plot was cultivars which consisted of six dual-purpose cultivars and two controls. The storage root yields, vine yields, starch yields and the reduction in storage root yields were observed. The results showed that the vine pruning decreased the storage root yields, with small increases the vine yields. The percentage of the reduction in storage root yields were 4-58\%, while the decrease vine yields are relatively inconsistent. The starch yield of the cultivars with one pruning time were in the range of 2.34-6.67 ton $\mathrm{ha}^{-1}$. On the contrary, the three times pruning or more since 80 days after transplanted can reduce the starch yields for more than $50 \%$. The slight increase in vines yield due to pruning was followed by the decrease in storage root yields and starch content of the sweet potato.
\end{abstract}

Keywords: dual-purpose sweet potato; pruning; starch yield; storage root yields; vine yields

Cite this as: Indawan, E., Lestari, S. U., Thiasari, N., \& Sasongko, P. (2020). The Pruning Effect on the Storage Root Yield and Starch Content of Sweet Potato Clones Planted at Dry Land. Caraka Tani: Journal of Sustainable Agriculture, 35(2), 289-298. doi: http://dx.doi.org/10.20961/carakatani.v35i2.34480

\section{INTRODUCTION}

Sweet potatoes are food crops with wide ecological adaptability, drought-tolerant, often cultivated in the marginal soils under low agricultural input and are able to grow with limited water available for irrigation (Motsa et al., 2015a; Motsa et al., 2015b; Chipungu et al., 2018; Lestari et al., 2019). Sweet potato plantations can reduce soil erosion because of its vines' ability to cover the soil surface (Oshunsanya, 2016). Sweet potatoes were mostly planted in the dry season (Bunphan and Anderson, 2019) and the soil loss from sweet potato harvest is lower than the other crops such as potato, groundnut and vegetables both from mono as well as double croplands ( $\mathrm{Yu}$ et al., 2016; Nanda et al., 2019). Thus, the sweet potatoes are suitable to be cultivated to support a sustainable agriculture system.

Sweet potatoes potential as a dual-purposes crop, i.e. harvesting the vines as livestock feed and harvesting the storage root for human consumption and/or bio-fuel (Megersa et al., 2012; Mussoline and Wilkie, 2017). According to Shumbusha et al. (2017), the dual-purpose sweet potato clones are the ones which have

\footnotetext{
* Received for publication July 9, 2019

Accepted after corrections August 18, 2020
} 
combinations of high storage root yields and vine production. Sweet potato has the capabilities to produce a large amount of vines as a feed source, aside from the yields of storage roots. According to Indawan et al. (2018), sweet potato cultivars planted on dry land were able to produce storage roots ranging from 10-23 ton ha ${ }^{-1}$ and vines ranging from 5-24 ton $\mathrm{ha}^{-1}$ in four months. Other research of sweet potato on dry land showed that the crop produced as much as 5.35-17.47 ton $\mathrm{ha}^{-1}$ of storage roots and 11.76-22.88 ton $\mathrm{ha}^{-1}$ of vines. Whereas when planted on paddy fields, the production of storage roots could reach 19.9064.52 ton $\mathrm{ha}^{-1}$ and vines ranging from 11.9132.09 ton $\mathrm{ha}^{-1}$ (Lestari et al., 2019).

Sweet potato cultivations are mostly for dualpurpose use; both for human food or biofuel and livestock feed, needs to be developed and improved. However, information on agronomic practices to produce storage roots and vines optimally is still limited. The vines of sweet potato are quite abundant at harvest, Lestari and Hapsari (2015) showed that sweet potato plantation was able to produce vine yields ranging from 5-56 ton ha $\mathrm{h}^{-1}$ on fresh weight or 2-7 ton $\mathrm{ha}^{-1}$ on dry weight. Similarly, another study on three cultivars, found that the plantation was able to provide its fresh vines ranging from 14.9-53.5 ton $\mathrm{ha}^{-1}$ and dry vines of 2.3-7.9 ton ha ${ }^{-1}$ (Mussoline and Wilkie, 2017). This illustrates that the volume of forage is big enough to be utilized as animal feed.

According to Sirait and Simanihuruk (2010) and Baba et al. (2018), sweet potato vines as an agricultural by product can be used as livestock feed due to its availability and nutritional values. The criteria for high nutritional values of the animal feed from sweet potato vines must be based on relatively lower NDF (Neutral Detergent Fiber) values; whereas according to Irungu et al. (2015) and Mbithe et al. (2016), the nutritional values were evaluated through the digestibility of organic matter in vitro (IVOMD), metabolic energy (ME), yields of fatty acids and crude protein. Sweet potato vines contain low carbohydrate and high crude protein content which can reach up to 29\%; so it can be used as a feed source to improve meat quality (Van An et al., 2003; Abonyi et al., 2012). Sweet potatoes storage roots from different cultivars evaluated in Sudan (Baba et al., 2018) had a range of crude protein content ranging from 10.82-20.58\%; whereas from three cultivars evaluated in Florida, the United States had a range of 124-141 $\mathrm{g} \mathrm{kg}^{-1}$ $(\approx 12.4-14.1 \%)$ based on their dry weight (Mussoline and Wilkie, 2017).

The nutritional values of the sweet potato vines (shoot) decrease with increasing harvest age and 120 days after planting (DAP) is recommended as the suitable age for harvesting (Irungu et al., 2015). The harvest age of sweet potato shoot can be regulated to obtain the optimum quality of the shoot nutritional contents. Some researchers have evaluated the time of pruning for various purposes (Van An et al., 2003; Olorunnisomo, 2007; Ahmed, 2012; Irungu et al., 2015; Jayanti et al., 2016; Suminarti, 2016; Suminarti and Novriani, 2017; Novianti and Setiawan, 2018; Netsai et al., 2019). In general, the researchers indicate the effect of pruning on the growth components and the storage root yields. In addition, the reduction of storage root yields, when followed by a decrease in starch content in sweet potatoes, is a very important variable to be considered if the sweet potatoes were used in the production of bioethanol.

In Indonesia, sweet potato pruning generally intended to reduce the sweet potato vegetative growth when the crops were cultivated in the rainy season (Mwololo et al., 2012). Excessive vegetative growth can inhibit the formation of storage root (Gajanayake and Reddy, 2016; Saitama et al., 2017). However, evaluating the pruning frequency to collect forage for animal feed needs to be done and several studies have been carried within the topic of interest by Olorunnisomo (2007) and Irungu et al. (2015) although the information is still limited in Indonesia.

Therefore, the effect of periodic pruning of sweet potato vines for livestock feed source on the storage root yield and its starch need to be observed. This study aims to evaluate the effect of the pruning on vines and storage root yields as well as the starch content of dual-purpose sweet potato clones.

\section{MATERIALS AND METHOD}

\section{Experimental site}

The experiment was conducted at the Research Station of Brawijaya University in Kromengan Sub-district, Malang Regency. The location is $7^{\circ} 21^{\prime} 14.6^{\prime \prime}$ South Latitude and $110^{\circ} 10^{\prime} 23.8^{\prime \prime}$ East Longitude with an altitude of approximately 390 meters above sea level (m asl) (Village Official 
Website of Jatikerto, Kromengan Sub-district, Malang Regency). The results of soil analysis of the location were as follows: $\mathrm{pH} \mathrm{H}_{2} \mathrm{O} 5.5\left(\mathrm{pH}_{\mathrm{KCl}}\right.$ $=4.9$ ), $\mathrm{C}$-org $0.87 \%$ (very low) and N-total $0.09 \%$ (very low), P-available $0.76 \mathrm{mg} \mathrm{g}^{-1}$ (very low), CEC 18.96 me $100 \mathrm{~g}^{-1}$ (medium) and base saturation 67 (high). The texture class of soil is clay with a fraction of sand, silt and clay of $17 \%$, $35 \%$ and $48 \%$, respectively. The lands marked as very intensive for crop cultivation. Following Sitorus et al. (2011), the land criteria have been degraded based on the silt percentages fraction between $20-40 \%$, P-available is at the very low level $(<3 \mathrm{ppm})$ and the intensive cultivation of land for food crops was included in severe degradation criteria. The experiment took place from April to September 2018.

\section{Materials}

The materials used in this experiment were consisted of eight sweet potato cultivars, namely: Kuningan Putih $\left(\mathrm{V}_{1}\right)$, Beta $2\left(\mathrm{~V}_{2}\right)$, Kuningan Merah ( $\left.\mathrm{V}_{3}\right)$, BIS OP-61 $\left(\mathrm{V}_{4}\right), 73-\mathrm{OP}-5\left(\mathrm{~V}_{5}\right)$, Beta 2-ㅇ-29 ( $\left.\mathrm{V}_{6}\right)$, BIS OP-61-OP-22 $\left(\mathrm{V}_{7}\right)$ and Sari $\left(\mathrm{V}_{8}\right)$. Kuningan Putih and Kuningan Merah are two local cultivars from Kuningan Sub-district (West Java), Beta 2 and Sari are high yield varieties which has been released. The remaining four cultivars are our research collections, which were deposited at the Research Station of Brawijaya University in Kromengan Sub-district, Malang Regency. The eight cultivars consisted of two types of sweet potato, the dual-purpose type and the high root-storage production type, as presented in Table 1.

Table 1. Sweet potato cultivars and their growth types ("Lestari and Hapsari, 2015)

\begin{tabular}{cll}
\hline No. & \multicolumn{1}{c}{ Cultivar $^{*}$} & \multicolumn{1}{c}{ Growth type } \\
\hline 1. & Kuningan Putih & Low dual purpose \\
2. & Beta & High dual purpose \\
3. & Kuningan Merah & Low dual purpose \\
4. & BIS OP-61 & Low dual purpose \\
5. & 73-OP-5 & High dual purpose \\
6. & Beta 2-9-29 & High dual purpose \\
7. & BIS-OP-61-OP-22 & High root production \\
8. & Sari & High root production \\
\hline
\end{tabular}

\section{Experimental design and treatment}

A split-plot design was used for this study with three replications. Two experimental factors included the vines pruning as the first factor as the main plot and the dual-purpose cultivars as the second factor laid out in a subplot. The pruning frequency of vines $(\mathrm{P})$ consisted of four levels; which were P80 (pruning four times at $80,90,120$ and 150 DAP), P90 (pruning three times at 90, 120 and 150 DAP), P120 (pruning twice at 120 and 150 DAP) and P150 (once pruning at 150 DAP). The sweet potato of dual-purpose cultivars, were 1) Kuningan Putih, (2) Beta 2, (3) Kuningan Merah, (4) BIS OP-61, (5) 73-OP-5 and (6) Beta 2-9-29, as presented in Table 1. Besides the dualpurpose cultivars, two other cultivars were also planted as controls. The cultivars chosen as the control varieties were based on the types of storage root production, namely BIS OP-61-OP22 and Sari (Lestari and Hapsari, 2015). All plants were given the fertilizer of $300 \mathrm{~kg} \mathrm{NPK} \mathrm{ha}{ }^{-1}$ and
$100 \mathrm{~kg} \mathrm{KCl} \mathrm{ha}^{-1}$ and 5 ton ha-1 of the biochar. Biochar was applied entirely at the time of tillage, NPK and $\mathrm{KCl}$ gave twice 1/3 part at $7 \mathrm{DAP}$ and the rest at 45 DAP.

The study used four rows of plots each measuring $5 \times 2.5 \mathrm{~m}^{2}$. The sweet potatoes were planted with cuttings of $\pm 25 \mathrm{~cm}$ long and with a spacing of $25 \mathrm{~cm}$ in a row. Each plot was populated with 40 cuttings. Vines harvesting was carried out periodically according to the treatment of vines pruning, but the storage root harvest was carried out at 150 DAP (5 months). Trimming volume of $25 \%$ is applied every time of pruning following (Netsai et al., 2019).

\section{Data analysis}

The observed variables were storage root yields, vines yield, percentages of storage root yields reduction and starch yields. The storage root yields, vine yields and starch yields were measured based on the total population of 40,000 plants $\mathrm{ha}^{-1}$. The data collected were analyzed by 
ANOVA method according to the Split Plot Design following (Gomez and Gomez, 1984). Treatment means presented with the associated standard error of the means (S.E.) with alpha at $1 \%$.

\section{RESULTS AND DISCUSSION}

\section{The storage root yields based on the pruning frequency}

Sweet potato pruning was intended to collect forages for animal feed. However, this pruning had an impact on storage root yield. The P150 treatment with once pruning, P120 with twice pruning, P90 with three times pruning and P80 with four times pruning, had significantly different storage root yield $(\mathrm{p}<0.01)$ as presented in Figure 1. The results showed that storage root yields decreased with increasing frequency of pruning. The decrease in root yields were varied depend on the sweet potato cultivars. In general, in treatment P80 and P90 the pruning effect greatly reduced the storage root yield, ranged between 5.63-18.14 ton $\mathrm{ha}^{-1}$ at P80 and 7.27-18.68 ton $\mathrm{ha}^{-1}$ at P90. Meanwhile, the pruning at P120 was relatively not different with the pruning at treatment P150 DAP (13.01-25.26 ton ha ${ }^{-1}$ at P120 and 13.54-33.82 ton $\mathrm{ha}^{-1}$ at $\mathrm{P} 150$ respectively). The storage root yields between Kuningan Putih, 73-OP-5 and Sari were relatively similar from each other when they were pruned twice (P120) to those that were pruned once (P150).

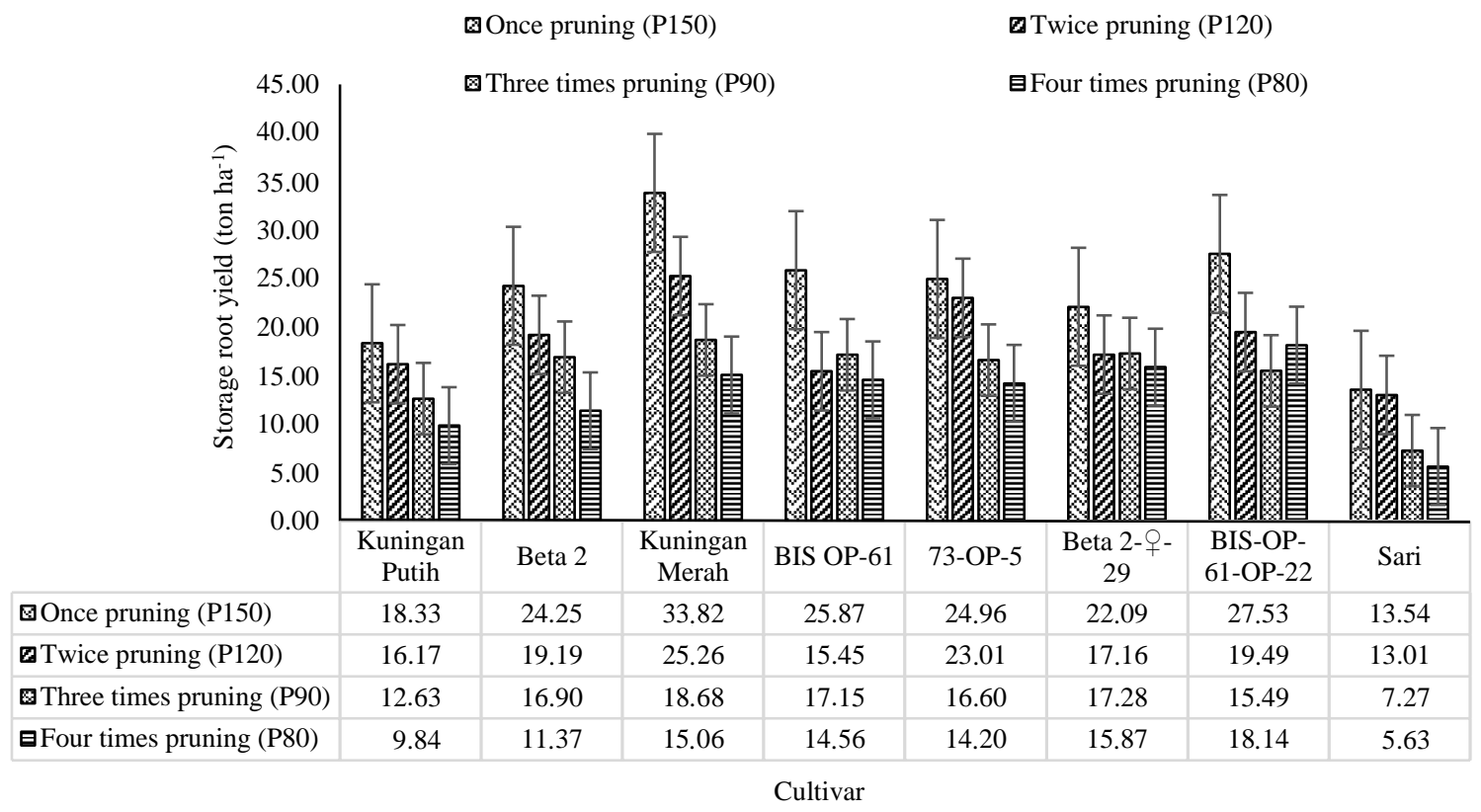

Figure 1. The storage root yield of eight sweet potato cultivars as affected by the pruning frequency treatments (Bars are SE)

Our study was in agreement with the research of Van An et al. (2003) they showed that the periodic defoliations on sweet potatoes affected the storage root yield, the root yield decreased by $20 \%$ when the vines were harvested with the interval of 30 days (a total of two harvests) with the removal of up to $50 \%$ of the vine. The research by Ahmed (2012) was carried out on the highland (740 $\mathrm{m}$ asl) with vines harvesting was done in a way that all vines of each plant were cut back to $10 \mathrm{~cm}$ above ground level at 45, 75 and 105 DAP, the results also showed decrease in storage root yield in the standard sweet potato cultivar in Ethiopia. The difference between our research and the research of Van An et al. (2003) and Ahmed (2012) lies at the age of pruning and the proportion of vines harvested. Time age of first pruning, the frequency of pruning and the proportionality of vines cutting tend to significantly decrease the root yields, in opposite with the increasing of the vine yields. Inline with Jayanti et al. (2016), defoliation affected storage root weight per plant as well as fresh root yield per hectare. However, our study is very different from 
the research of Niyireba et al. (2013) where the pruning increased vine yields without reducing root yields.

Defoliation generally affected storage root production, which can be explained by the experiment results which showed that the vines are negatively correlated with root yields (Enyi, 1977). Increasing the frequency of vine harvests increased the partitioning of assimilates to vines (Gomes et al., 2005). Findings in the current study suggested that a highly significant reduction in root yields due to the pruning is attributed to the increased assimilates deposition into the vines as explained by Gomes et al. (2005). The reduction in root yields is very detrimental to staple food production. Therefore, the harvest of vines during the growth of sweet potato plants are not recommended because the adverse will to the storage root yields.

\section{The vine yields based on the frequency of pruning}

The pruning of sweet potato vines periodically did not affect the vine production $(\mathrm{p}>0.05)$, but there are differences in vine yields among the cultivars evaluated $(p<0.01)$. The vine yields of the cultivar with one a time pruning (P150) varied in different cultivars, ranging from 4.75-25.02 ton $\mathrm{ha}^{-1}$ (Figure 2). When the pruning conducted more than once, however, all of the cultivars showed different responses in the vine yields. Among eight cultivars, two of them had doubled their total vine yields when the pruning was carried out, namely Kuningan Putih and 73-OP-5. However, two other cultivars showed relatively no changes in the total of vine yields, namely Kuningan Merah and BIS OP-61 (Figure 2). The varying vine yields due to in this study is in line with the research conducted by Novianti and Setiawan (2018) as well as Suminarti and Novriani (2017). Novianti and Setiawan (2018) showed that pruning activities on sweet potato could improve vegetative growth, whereas Suminarti and Novriani (2017) indicated that the treatment of defoliation effects various components of growth, such as number of branches, number of leaves, leaf area and total fresh weight of foliage.

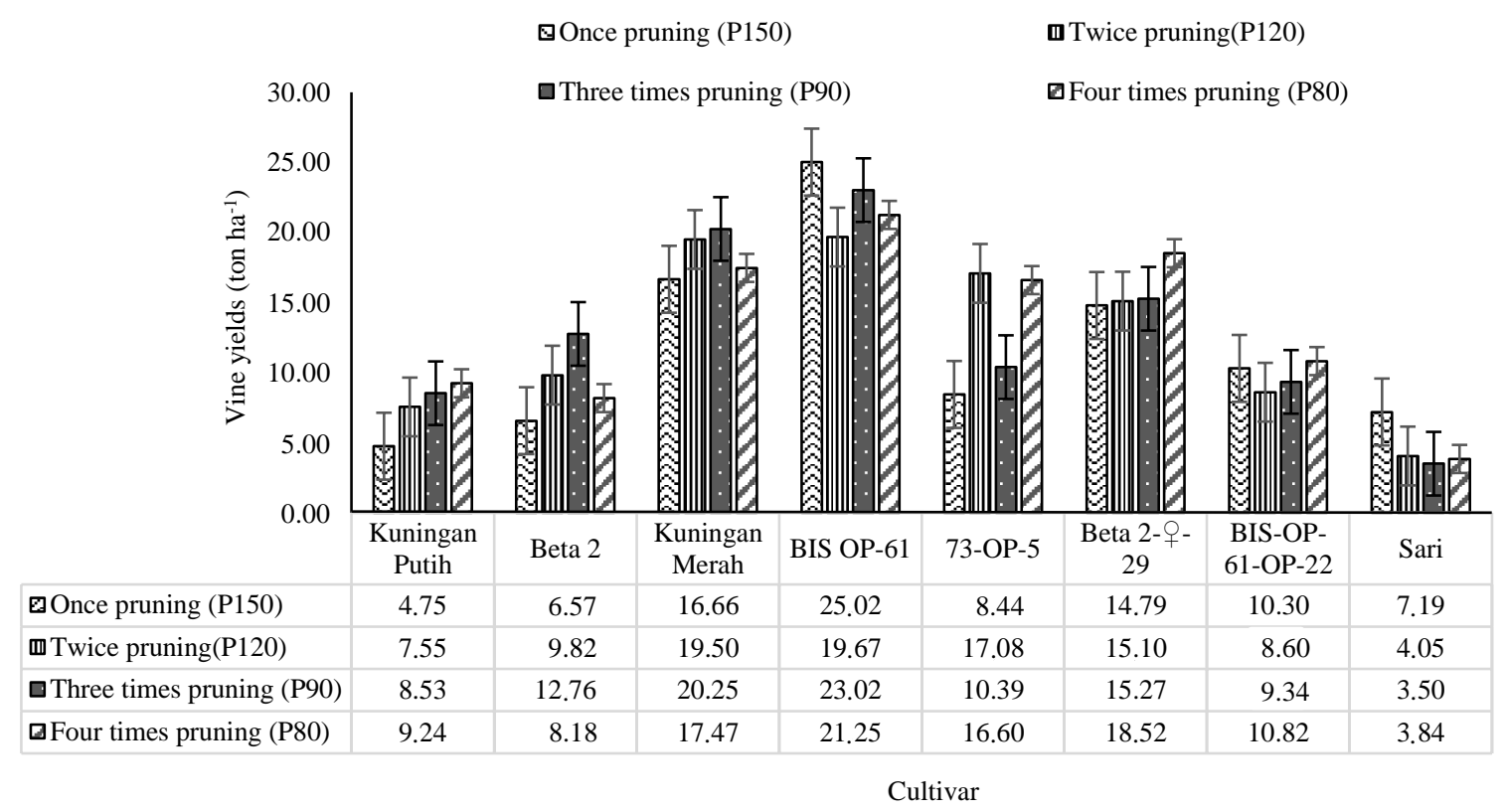

Figure 2. The vine yields of eight sweet potato cultivars as affected by the vines' pruning frequency treatments

The parameters of total vines harvested were analyzed. Highly significant differences $(p>0.01)$ were found among the eight experimental cultivars, meaning that there are differences in potential or ability to produce vines among these cultivars. Sari cultivar produced the lowest amount of vine, in the range of 3.50 ton ha ${ }^{-1}$ to 7.19 ton ha ${ }^{-1}$. Whereas BIS-OP-61 cultivar had the highest potential to produce fresh vines, which can reach up to 19.67-25.02 ton ha-1. 
Thus, the yield of vines was less likely to be affected by the frequency of pruning on sweet potato plants (Figure 2). Similar results had been reported by Van An et al. (2003). The amount of storage root yield is still the major factor to be considered when deciding on how to harvest the vines of sweet potato for animal feed purposes. Our research implies that it is better not to harvest the sweet potato vines during the growth, to cultivate the sweet potato in successive time so that the vine harvest can be carried out continuously based on the desired amount of animal feed is a better option.

\section{The percentages of reduction in storage root and starch yield}

The decreases in storage root yields due to the pruning frequency at different ages of plant growth (P80, P90 and P120) were varied when compared to one time pruning at $150 \mathrm{DAP}(\mathrm{P} 150)$ treatment. The largest storage root yield decrease were observed at P80, where the vines were harvested for four times and a crop was beginning to be pruned at the age of $80 \mathrm{DAP}$. The decreasing range of root yields reached $28-58 \%$ compared to the one-time pruning treatment. In the treatment where the vines were pruned at 90 DAP (P90), a decrease in root yield of $21.77-46.30 \%$ were observed. Whereas in the treatments where the pruning were conducted at the age of 120 DAP the decrease in storage root yield was only in the range between $3.91-40.28 \%$ (Table 2). The reduced storage root yields due to the vine pruning during the growth period is very large, although the values varied among the sweet potato clones. Variation in root yields decrease among the sweet potato clones was caused by the level of photosynthetic translocation efficiency in each cultivar (Austin and Aung, 1973).

Table 2. The percentage of reduction in storage root yield (\%) against to P150 in response to the frequency of pruning on the eight sweet potato cultivars

\begin{tabular}{cllrrr}
\hline \multirow{2}{*}{ No. } & Clone & \multirow{2}{*}{ Sweet potato type } & \multicolumn{3}{c}{ \% reduction of storage root yields *) } \\
\cline { 3 - 5 } & & Low dual purpose & 46.28 & 31.10 & 11.74 \\
\hline 1. & Kuningan Putih & High dual purpose & 53.13 & 30.32 & 20.86 \\
2. & Beta 2 & Low dual purpose & 55.47 & 44.78 & 25.32 \\
3. & Kuningan Merah & Low dual purpose & 43.70 & 33.71 & 40.28 \\
4. & BIS OP-61 & High dual purpose & 43.09 & 33.50 & 7.81 \\
5. & 73-OP-5 & High dual purpose & 28.15 & 21.77 & 22.30 \\
6. & Beta 2-9-29 & High root production & 34.12 & 43.76 & 29.23 \\
7. & BIS-OP-61-OP-22 & High root production & 58.37 & 46.30 & 3.91 \\
8. & Sari & &
\end{tabular}

Note: ${ }^{*}$ Measurements for decreasing of root yields are based on root yields of P150, where at the P150, the vines are only harvested once at the time of harvest or no pruning during plant growth

Two clones have very small decrease in root yields, only ranging between $3.91-7.81 \%$, which were the 73-OP-5 and Sari, when pruned at the age of 120 DAP. The decrease in storage root yields in other clones were more than $10 \%$ one particular cultivar (BIS OP-61), however, had a decrease of $40 \%$ (Table 2). A decreased the yield of storage roots, can be explained by the decline in photosynthetic translocation to the storage root due to being diverted for the growth of vines. According to Gomes et al. (2005) the frequency of vine harvests increased the partitioning of assimilates to vines. Likewise, according to Laurie et al. (2015) the vines grow above the ground had a direct effect on storage root growth below-ground.
The decrease in storage root yields, when followed by a decrease in starch content in sweet potatoes, are crucial to know especially when the sweet potatoes are used as the material for the manufacture of bioethanol. The measurement of starch content and its conversion to the estimation of starch yield are presented in Figure 3 . The starch yield in sweet potato cultivars which were pruned once was in the range of 2.346.67 ton $\mathrm{ha}^{-1}$. The pruning of three to four times during the growth period starting at 80 DAP reduces the starch yield by more than $50 \%$. The effect of pruning on the decrease in starch yields is highly dependent on the cultivar $(p<0.01)$; because storage root yields were also highly variable $(\mathrm{p}<0.01)$. 


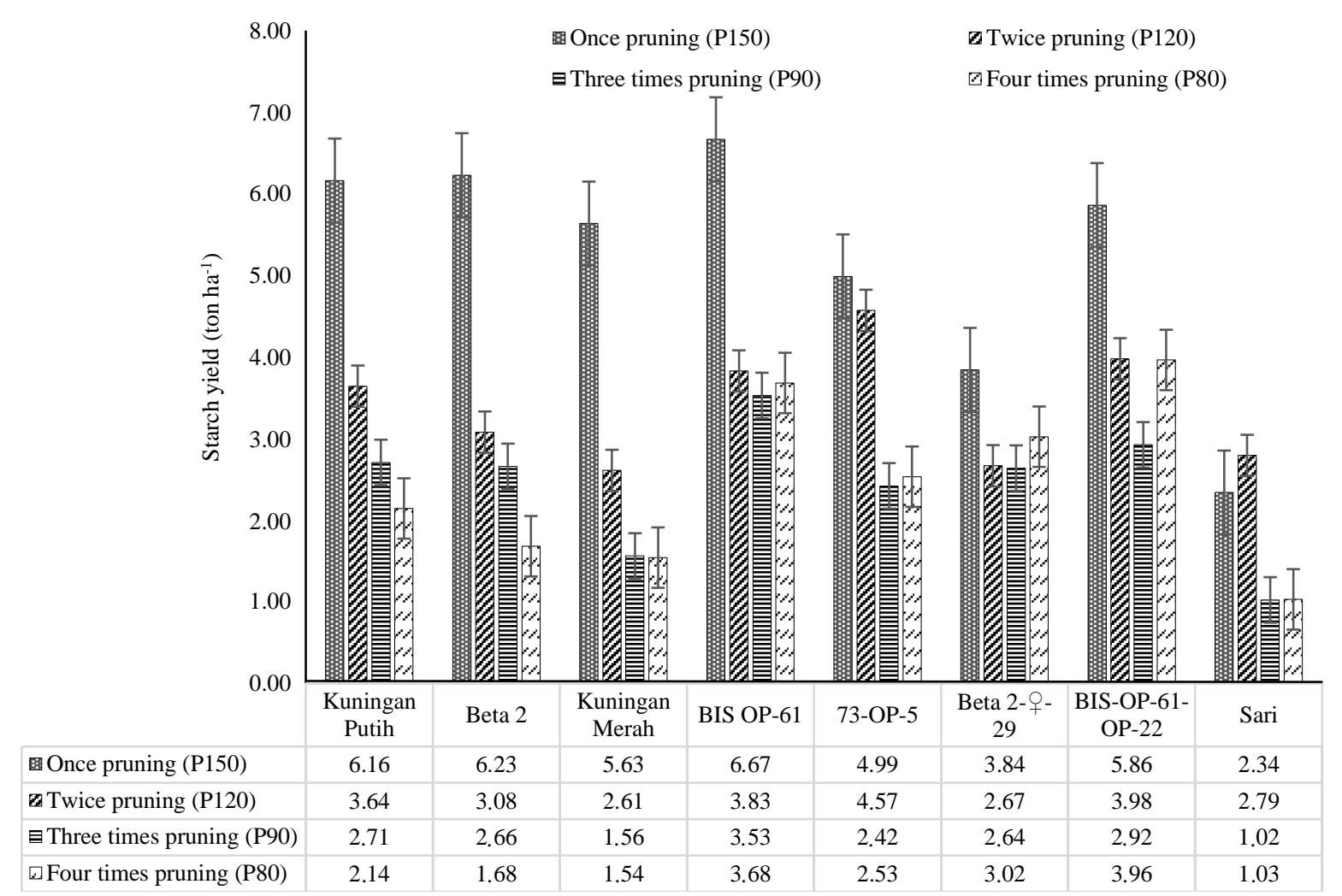

Figure 3. The starch yield of eight sweet potato cultivars highly varied at different pruning frequency treatments

The reduction in the storage root yields and their yields of starch should be considered in the cultivation of dual-purpose sweet potato. The required considerations included whether the pruning periods and the frequency affect the nutritional values of the vines as animal feed and whether the pruning also lowers the starch yields of the sweet potato. These are important when considering that the sweet potato cultivation was intended for the supply of food, feed and fuel (bioethanol).

\section{CONCLUSIONS}

The time of pruning and their frequency could reduce the storage root and starch yields, but only have a little effect to the increase in vine yields. The percentage of the reduction in the storage root yield reached 3.91-58.37\%, while the increase of vines yields were inconsistent. The pruning treatment decreased the starch yields and the decrease were varied among the cultivars, trimmed 2-3 times since the age of 80 DAP can reduce starch yields for more than $50 \%$.

\section{ACKNOWLEDGEMENT}

The authors thank the Directorate General of Strengthening for Research and Development, Ministry of Research, Technology and Higher Education for funding this research. The technical support from Brawijaya University Agrotechnopark and Indonesian Legume and Storage Crops Research Institute (ILETRI), are also acknowledged.

\section{REFERENCES}

Abonyi, F. O., Iyi, E. O., \& Machebe, N. S. (2012). Effects of feeding sweet potato (Ipomoea batatas) leaves on growth performance and nutrient digestibility of rabbits. African Journal of Biotechnology, 11(15), 3709-3712. Retrieved from https:// www.ajol.info/index.php/ajb/article/view/100 883

Ahmed, M. (2012). Effect of planting methods and vine harvesting on a shoot and tuberous root yields of sweet potato [Ipomoea batatas (L.) Lam.] in the Afar region of Ethiopia. 
African Journal of Agricultural Research, 7(7), 1129-1141. Retrieved from https://www. researchgate.net/publication/266030457_Effe ct_of_planting_methods_and_vine_harvesting _on_shoot_and_tuberous_root_yields_of_swe et_potato_Ipomoea_batatas_L_Lam_in_the_ Afar_region_of_Ethiopia

Austin, M. E., \& Aung, L. H. (1973). Patterns of dry matter distribution during development of sweet potato (Ipomoea batatas). Journal of Horticultural Science, 48(1), 11-17. https:// doi.org/10.1080/00221589.1973.11514502

Baba, M., Nasiru, A., Karkarna, I. S., Muhammad, I. R., \& Rano, N. B. (2018). Nutritional evaluation of sweet potato vines from twelve cultivars as feed for ruminant animals. Asian Journal of Animal and Veterinary Advances, 13(1), 25-29. https://doi.org/10.3923/ajava. 2018.25.29

Bunphan, D., \& Anderson, W. F. (2019). Effect of planting pattern and season on some agronomic performances and yield of sweet potato cv. Japanese Orange. Australian Journal of Crop Science, 13(7), 1067-1073. https://doi.org/10.21475/ajcs.19.13.07.p1522

Chipungu, F., Changadeya, W., Ambali, A., Saka, J., Mahungu, N., \& Mkumbira, J. (2018). Adaptation of sweet potato [Ipomoea batatas (L.) Lam] genotypes in various agroecological zones of Malawi. African Journal of Biotechnology, 17(16), 531-540. https://doi. org/10.5897/ajb2017.16352

Enyi, B. A. C. (1977). Analysis of tuber yield in sweet potato (Ipomea batatas) cultivars. The Journal of Agricultural Science, 88(2), 421430. https://doi.org/10.1017/S0021859600034 936

Gajanayake, B., \& Reddy, K. R. (2016). Sweet potato responses to mid-and late-season soil moisture deficits. Crop Science, 56(4), 18651877. https://doi.org/10.2135/cropsci2015.03. 0154

Gomes, F., Carr, M. K. V., \& Squire, G. R. (2005). Effects of water availability and vine harvesting frequency on the productivity of sweet potato in Southern Mozambique. IV. Radiation interception, dry matter production, and partitioning. Experimental Agriculture, 41(1), 93-109. https://doi.org/10.1017/S0014

\section{2}

Gomez, K. A., \& Gomez, A. A. (1984). Statistical procedures for agricultural research (Second Eds). New York: John Wiley \& Sons. Retrieved from https://pdf.usaid.gov/pdf_docs /PNAAR208.pdf

Indawan, E., Lestari, S. U., \& Thiasari, N. (2018). Sweet potato response to biochar application on sub-optimal dry land. Journal of Degraded and Mining Lands Management, 5(2), 11331139. https://doi.org/10.15243/jdmlm.2018.05 2.1133

Irungu, R., Migwi, P. K., Kariuki, J. N., \& Guliye, A. Y. (2015). Determination of suitable harvesting age of selected forage sweet potato cultivars to achieve high nutritive value in ruminants. The 2015 JKUAT Scientific Conference, 1, 57-66. Retrieved from http:// journals.jkuat.ac.ke/index.php/jscp/article/vie $\mathrm{w} / 1236$

Jayanti, A., Sunaryo, \& Widaryanto, E. (2016). Pengaruh tingkat defoliasi pada pertumbuhan dan hasil tiga varietas ubi jalar (Ipomoea batatas L.). Jurnal Produksi Tanaman, 4(7), 503-511. Retrieved from http://protan.student journal.ub.ac.id/index.php/protan/article/view 1322

Laurie, R. N., Laurie, S. M., Du Plooy, C. P., Finnie, J. F., \& Van Staden, J. (2015). The yield of drought-stressed sweet potato in relation to canopy cover, stem length, and stomatal conductance. Journal of Agricultural Science, 7(1), 201-214. https://doi.org/ 10.5539/jas.v7n1p201

Lestari, S. U., \& Hapsari, R. I. (2015). Dualpurpose assessment for sweet potato. AGRIVITA, 37(2), 123-129. https://doi.org/ 10.17503/Agrivita-2015-37-2-p123-129

Lestari, S. U., Hamzah, A., \& Julianto, R. P. D. (2019). Alteration agronomic traits performance of sweet potato cultivars from drylands to paddy fields. Journal of Degraded and Mining Lands Management, 6(3), 17631769. https://doi.org/10.15243/jdmlm.2019.06 3.1763

Mbithe, M. J., Steven, R., Agili, S., Kivuva, M. B., Kioko, W. F., \& Kuria, E. (2016). Proximate characterization of selected ugandan sweet potato (Ipomoea batatas L.) 
varieties for food and feed. Advances in Crop Science and Technology, 4(2), 1-5. Retrieved from https://www.researchgate.net/publicatio n/303751392_an_open_access_journal_Proxi mate_Characterization_of_Selected_Ugandan _Sweetpotato_Ipomoea_Batata_L_Varieties_ For_Food_And_Feed

Megersa, T., Urge, M., \& Nurfeta, A. (2012). Effects of feeding sweet potato (Ipomoea batatas) vines as a supplement on feed intake, growth performance, digestibility and carcass characteristics of Sidama goats fed a basal diet of natural grass hay. Tropical Animal Health and Production, 45(1), 593-601. https://doi. org/10.1007/s11250-012-0264-4

Motsa, N. M., Modi, A. T., \& Mabhaudhi, T. (2015a). Influence of agro-ecological production areas on antioxidant activity, reducing sugar content, and selected phytonutrients of orange-fleshed sweet potato cultivars. Food Science and Technology, 35(1), 32-37. https://doi.org/10.1590/1678$457 \mathrm{X} .6443$

Motsa, N. M., Modi, A. T., \& Mabhaudhi, T. (2015b). Sweet potato response to low-input agriculture and varying environments of KwaZulu-Natal, South Africa: implications for food security strategies. Acta Agriculturae Scandinavica Section B: Soil and Plant Science, 65(4), 329-340. https://doi.org/ 10.1080/09064710.2015.1011222

Mussoline, W. A., \& Wilkie, A. C. (2017). Feed and fuel: the dual-purpose advantage of an industrial sweet potato. Journal of the Science of Food and Agriculture, 97(5), 1567-1575. https://doi.org/10.1002/jsfa.7902

Mwololo, J. K., Mburu, M. W. K., \& Muturi, P. W. (2012). Performance of sweet potato varieties across environments in Kenya. International Journal of Agronomy and Agricultural Research, 2(10), 2223-7054. Retrieved from https://www.researchgate.net/ publication/239735257_Performance_of_swe et_potato_varieties_across_environments_in_ Kenya

Nanda, B. K., Sahoo, N., \& Panigrahi, B. (2019). Assessment of soil loss from agricultural lands of South Andaman District in Tropical Islands. International Journal of Current Microbiology and Applied Sciences, 8(03), 2190-2198. https://doi.org/10.20546/ijcmas.2019.803.262

Netsai, N., Moses, M., \& Tuarira, M. (2019). Effect of cutting position and vine pruning level on a yield of sweet potato (Ipomoea batatas L.). Journal of Aridland Agriculture, 5, 1-5. Retrieved from https://doi.org/ 10.25081/jaa.2019.v5.5255

Niyireba, T. N., Ebong, C., Agili, S., Low, J., Lukuyu, B., Kirui, J., Ndirigwe, J., Uwimana, G., Kakundiye, L., Mutimura, M. Gahakwa, D., \& Gachuiri, C. K. (2013). Evaluation of dual-purpose sweet potato [Ipomea batatas (L.) Lam] cultivars for root and fodder production in Eastern Province, Rwanda. Agricultural Journal, 8(5), 242-247. Retrieved from https://medwelljournals.com/ abstract/?doi=aj.2013.242.247

Novianti, D., \& Setiawan, A. (2018). Pengaruh pemangkasan pucuk dan jarak tanam terhadap pertumbuhan dan produksi bibit ubi jalar (Ipomoea batatas L.). Buletin Agrohorti, 6(1), 143-153. https://doi.org/10.29244/agrob.6.1. $143-153$

Olorunnisomo, O. A. (2007). Yield and quality of sweet potato forage pruned at different intervals for West African dwarf sheep. Livestock Research for Rural Development, 19(3), 3-8. Retrieved from http://www.lrrd. org/lrrd19/3/olor 19036.htm

Oshunsanya, S. O. (2016). Alternative method of reducing soil loss due to harvesting of sweet potato: A case study of low input agriculture in Nigeria. Soil and Tillage Research, 158, 4956. https://doi.org/10.1016/j.still.2015.11.007

Saitama, A., Nugroho, A., \& Widaryanto, E. (2017). Yield response of ten varieties of sweet potato (Ipomoea batatas L.) cultivated on dryland in rainy season. Journal of Degraded and Mining Lands Management, 04(04), 919 926. https://doi.org/10.15243/jdmlm.2017.044 .919

Shumbusha, D., Shimelis, H., Laing, M., \& Asiimwe, T. (2017). Phenotypic diversity analysis of sweet potato for breeding dualpurpose varieties. Acta Agriculturae Scandinavica Section B: Soil and Plant Science, 67(4), 340-351. https://doi.org/ $10.1080 / 09064710.2017 .1281431$

Sirait, J., \& Simanihuruk, K. (2010). Potensi dan 
pemanfaatan daun ubikayu dan ubijalar sebagai sumber pakan ternak ruminansia kecil. Wartazoa, 20(2), 75-84. Retrieved from http://medpub.litbang.pertanian.go.id/index.p $\mathrm{hp} /$ wartazoa/article/download/940/949

Sitorus, S., Susanto, B., \& Haridjaja, O. (2011). Kriteria dan klasifikasi tingkat degradasi lahan di lahan kering (Studi kasus : lahan kering di Kabupaten Bogor). Jurnal Tanah dan Iklim, 34, 66-83. Retrieved from https://media. neliti.com/media/publications/132975-IDnone.pdf

Suminarti, N. E. (2016). Pengaruh pemupukan N dan frekuensi pemangkasan tajuk pada aspek agronomis dan hasil tanaman ubi jalar (Ipomoea batatas (L.) Lam.) var. Kretek. Jurnal Agro, 3(2), 8-20. https://doi.org/10.155 $75 / 856$

Suminarti, N., \& Novriani, R. (2017). Pengaruh defoliasi dan posisi penanaman stek batang pada pertumbuhan dan hasil tanaman ubi jalar (Ipomoea batatas L.) Lam. Var. Sari. Jurnal Biodjati, 2(1), 21-29. https://doi.org/ 10.15575/biodjati.v2i1.1293

Van An, L., Frankow-Lindberg, B. E., \& Lindberg, J. E. (2003). Effect of harvesting interval and defoliation on yield and chemical composition of leaves, stems, and tubers of sweet potato (Ipomoea batatas L. (Lam.)) plant parts. Field Crops Research, 82(1), 4958. Retrieved from https://doi.org/10.1016/ S0378-4290(03)00018-2

Yu, H. Q., Li, Y., Zhou, N., Chappell, A., Li, X. Y., \& Poesen, J. (2016). Soil nutrient loss due to tuber crop harvesting and its environmental impact in the North China Plain. Journal of Integrative Agriculture, 15(7), 1612-1624. https://doi.org/10.1016/S2095-3119(15)6126 8-0 